\title{
Reformulation Markers in Non-Initial Position in Written English and Spanish ${ }^{1}$
}

\author{
Silvia Murillo Ornat ${ }^{2}$
}

\begin{abstract}
This article presents a contrastive analysis of non-initial positions (less common and, therefore, marked) of explanatory reformulation markers in written language in English and Spanish, in relation to their discursive uses. To carry out this analysis, the cases of these markers found in a comparable English-Spanish corpus (Cobuild and CREA) are analyzed. Four positions are established, initial, intermediate, final and independent (Pons 2014), and the results of the non-initial positions are related to the different discursive uses of these markers (Murillo 2012, 2016a, 2016b), taking into account their reformulative and modal uses. The results reveal that the markers in English - particularly that is, but also in other words-display more mobility than those in Spanish -the only one having some mobility is o sea. In addition, regarding their discursive uses, the analysis of the corpus reveals that the markers follow different trends in the two languages.
\end{abstract}

Keywords: contrastive study; discourse markers; reformulation markers; position; modal uses.

\section{[es] Los marcadores de reformulación en posición no inicial en inglés y español escrito}

Resumen. En el presente artículo se aborda un análisis contrastivo de las posiciones no iniciales (menos habituales y, por tanto, marcadas) de los marcadores de reformulación explicativa en lengua escrita en inglés y en español, en relación con sus usos discursivos. Para ello, se analizan los casos de estos marcadores encontrados en un corpus comparable inglés-español (Cobuild y CREA). Se establecen cuatro posiciones, inicial, intermedia, final e independiente (Pons 2014), y se relacionan los resultados de las posiciones no iniciales con los distintos usos discursivos de estos marcadores (Murillo 2012, 2016a, 2016b), teniendo en cuenta sus usos reformulativos y modales. Se constata que los marcadores en inglés - especialmente that is, aunque también in other words- presentan más movilidad que los marcadores en español -el único que presenta cierta movilidad es o sea-. Asimismo, en cuanto a sus usos discursivos, se comprueba cómo los marcadores siguen tendencias diferentes en las dos lenguas.

Palabras clave: estudio contrastivo; marcadores discursivos; marcadores de reformulación; posición; usos modales.

Contents. 1. Introduction: reformulation markers. 2. Methodological approach and background of the study. 2.1. Corpus. 2.2. Functions of reformulation markers. 2.3. Positions of reformulation markers. 3. Data analysis and results. 3.1. Global results. 3.2. Results of the english subcorpus: discourse markers and functions. 3.3. Results of the spanish subcorpus: discourse markers and functions. 3.4. Modal uses in the english and spanish subcorpora. 4. Concluding remarks.

How to cite this article: Murillo Ornat, S. (2021) Reformulation Markers in Non-Initial Position in Written English and Spanish, in Complutense Journal of English Studies 29, 35-48.

\section{Introduction: reformulation markers}

Reformulation is frequent in discourse: speakers and writers often go back to what they have said or written previously in order to clarify it, and they often use reformulation discourse markers for that purpose (Gülich \& Kotschi 1983; Charolles \& Coltier 1986). Reformulation and its markers are not restricted to less planned discourse; in more planned discourse they are used by writers to organize and present the content of their messages in a suitable way, for example by specifying and enumerating different elements (cf. Fløttum 1994). Furthermore, there are more complex uses of reformulation markers, as in some written journalistic genres, where they can be used to reflect orality in order to persuade the readers of the writers' arguments (Mancera 2008).

\footnotetext{
The research carried out to write this article was funded by the Spanish Ministerio de Economía, Industria y Competitividad (project FFI201784205-P), within the research group CIRES (Comunicación Internacional y Retos Sociales, H16_20R), supported by DGA (Diputación General de Aragón) and FEDER (Fondo Europeo de Desarrollo Regional). This study is also a contribution to the Research Institute of Employment, Digital Society and Sustainability (IEDIS).

2 Department of English and German Studies, University of Zaragoza

ORCID: 0000-0003-1369-3590

E-mail: smurillo@unizar.es
}

Complut. j. Engl. stud. 29 2021: 35-48 
Reformulation markers have been defined by José Portolés in the following way: "These markers present the discourse member in which they appear as a new formulation -that is, a new way of telling- of what was intended to be communicated in a previous discourse member" (2016: 695, my translation).

The classification proposed by Portolés includes several subgroups of reformulation markers, namely explicatives (reformuladores explicativos), rectificatives (reformuladores rectificativos), dissociatives (reformuladores de distanciamiento), recapitulatives (reformuladores de recapitulación) and reconsideration markers (reformuladores de reconsideración) (2016: 695).

In this paper, I consider the first subgroup, explicative reformulation markers, in English and in Spanish; they are referred to, for short, as "reformulation markers". Specifically, this subgroup includes the following items: in English, that is, that is to say, i.e., in other words, namely, and viz, and less grammaticalized markers such as (to put it) another way, and (to put it) simply; in Spanish, the markers es decir, o sea, esto es and a saber, and other less grammaticalized items such as (dicho) en otras palabras, (dicho) con otras palabras, (dicho/ por decirlo) en otros términos, dicho de otra forma, dicho de otra manera, dicho/ por decirlo de otro modo, (o) lo que es lo mismo and léase. Riegel and Tamba expressed the need to study the different reformulation markers in the following terms:

[W] hy do languages have such a range of "relating words" to express an "equivalence of meaning" between two "terms", while the mathematician is satisfied with the single symbol "="? What do these "relating words" have in common? And how do they differ from each other? (1987: 4, my translation)

Different studies have been carried out in several languages, such as those in French (Gülich \& Kotschi 1983; Charolles \& Coltier 1986; Murat \& Cartier-Bresson 1987), Spanish (Casado 1991; Schwenter 1996; Briz 2001, 2002; Garcés Gómez 2008), Greek (Archakis 2001), Japanese (Matsui 2002), English (del Saz 2003), German (Robles 2012), and Catalan (Bach 2017), among others. These studies have focused on single items or in groups/subgroups of markers, trying to establish their main uses. Reformulation markers have also been considered from a contrastive point of view in studies such as Fløttum (1994), Cuenca (2003), Vassiliadou (2004), Cuenca and Bach (2007), Garcés Gómez (2009), Pons and Macário (2014), and Murillo (2009, 2012, 2016a).

Although research on the position of discourse markers regarding the units in which they appear has recently become prominent (Montañez 2007; Pons 2008; Briz \& Pons 2010; Borreguero 2014; Estellés \& Pons 2014; Ghezzi \& Molinelli 2014; Tanghe 2016; Guillén 2018, among others), not much attention has been given to the position of reformulation markers, with the exception perhaps of Pons's account (2014) of the evolution of $o$ sea and of Robles's study (2019) of the position of German reformulation markers. This lack of attention might be attributed to the fact that most of the occurrences of these markers correspond to the initial position. However, as Borreguero indicates,

[D]iscourse units and the position of discourse markers inside the units [...] not only provide a basis for lexicographic studies but should also be an integral part of any accurate contrastive analysis if a clear picture of the shared and divergent uses of apparently equivalent discourse markers in different languages is to emerge (2014: 377).

Thus, the objective of my study is to take a first step towards a contrastive analysis of the position of reformulation markers in written English and Spanish, in relation with their uses. In particular, non-initial positions will be related with the different functions of these markers, taking into account their reformulative and modal uses. As will be seen in the corpus analyzed, some not so frequent uses of these discourse markers may be revealing of certain trends from a contrastive point of view.

The following section provides some background discussion and deals with the methodology applied to conduct the research: the corpus analyzed (with two components, English and Spanish) and the variables of the study, that is, the discourse processes introduced by reformulation markers, including other uses or functions that they can perform (mainly modal uses), and the positions they occupy in the discourse members where they appear. After this, I present the global results, the results of each subcorpus concerning reformulation processes and the results of the two subcorpora in relation to modal uses. Finally, I reach some conclusions and make some final remarks.

\section{Methodological approach and background of the study}

Regarding the methodology followed, the cases found in an English-Spanish comparable corpus of journalistic texts were analyzed. In order to carry out this analysis, four positions for reformulation markers were established in relation to the discourse member in which they appear; these positions were initial, intermediate, final and independent (following Briz \& Pons 2010; Pons 2014). After that, the results of non-initial positions were 
related to the reformulative and modal uses of the markers. The statistical program $R$ Commander (version 3.5.1) was used in order to cross the variables and display the data in different tables. The following subsections deal with the corpus, the taxonomy of functions of reformulation markers used as a framework, and the different positions analyzed.

\subsection{Corpus}

In order to do this contrastive analysis, all the cases of reformulation markers found in a corpus of contemporary British English (from COBUILDdirect, The Bank of English) and peninsular Spanish (compiled from the Corpus de Referencia del Español Actual, CREA) were examined. The components of the corpus selected were written journalistic materials and the total number of words of each subcorpus was approximately fifteen million words (see Figure 1 below). In this way, the two subcorpora were comparable to a great extent in terms of size, date and sources. The reason why journalistic language was chosen is that it is considered a representative use of written language, halfway between colloquial and formal. Previous research on this corpus includes Murillo (2009, 2010, 2015, 2016a, 2016b); the recent attention paid to research on the position of discourse markers has made it worthwhile to revisit this material of study.

\begin{tabular}{|l|l|}
\hline \multicolumn{1}{|c|}{ Spanish subcorpus } & \multicolumn{1}{|c|}{ English subcorpus } \\
\hline Total number of words: 14,925,946 & Total number of words: 15,914,053 \\
\hline $\begin{array}{l}\text { Sources: Spanish newspapers ( } \mathrm{La} \mathrm{Voz} \mathrm{de} \mathrm{Galicia,} \mathrm{La} \mathrm{Voz,} \mathrm{La} \\
\text { Vanguardia, El País Digital, El Mundo, El Diario Vasco, Ca- } \\
\text { narias 7, ABC Cultural and ABC) and magazines (1991-1996) } \\
\text { (CREA) }\end{array}$ & $\begin{array}{l}\text { Sources: British newspapers (The Times, The Sunday } \\
\text { Times and Today) and magazines (1991-1996) (CO- } \\
\text { BUILDdirect) }\end{array}$ \\
\hline $\begin{array}{l}\text { Total number of reformulation markers: 2,823 } \\
\text { Per million: } 189.13\end{array}$ & $\begin{array}{l}\text { Total number of reformulation markers: } 797 \\
\text { Per million: 50.08 }\end{array}$ \\
\hline
\end{tabular}

Figure 1. Corpus components and general data

As can be seen in Figure 1, in the Spanish subcorpus 2,823 examples with reformulation markers were found (with es decir, o sea, esto es, and a saber, and the less grammaticalized markers en/con otras palabras, en otros términos, o lo que es lo mismo, léase, de otro modo, and de otra manera/forma), while in the English subcorpus I found 797 cases (with that is, that is to say, i.e., in other words, namely and viz., and the less grammaticalized forms to put it simply and to put it in other words). That is, in Spanish reformulation markers were 3.5 times as frequent as in English. These data are in line with Cuenca's (2003) and suggest that English is a more linear language than Spanish, allowing fewer reformulations.

\subsection{Functions of reformulation markers}

In order to explain the variable of the functions of reformulation markers, a taxonomy is used that integrates those of Quirk et al. (1985), Gülich and Kotschi (1983), Charolles and Coltier (1986), Murat and CartierBresson (1987), and Fløttum (1994). This classification (Murillo 2012, 2016a, 2016b; Portolés et al. 2021) is based on Relevance Theory (Sperber \& Wilson 1986/1995; Blakemore 1993, 1996).

The taxonomy is both corpus-based and corpus-driven (following the terminology of Tognini-Bonelli 2001). That is, some functions that had already been considered in previous research were included, but then I found other examples in the corpus that allowed me to complete the classification and revealed that reformulation markers may be used in all the stages of the interpretation of utterances as explained by Relevance Theory. Thus, the taxonomy, which operates cross-linguistically, makes sense from a communicative point of view, as the markers are used by the writers/speakers to help the readers/hearers to interpret what they want to communicate, by restating it or making it explicit.

In this framework, the following processes are differentiated:

a. Processes related to the interpretation of explicit meaning (explicatures), including identification, specification and orientation, and the more global processes of explanation, introduction of restrictions and correction.

b. Processes related to the interpretation of implicit meaning (implicatures), including those related to the implicated premises, namely definition and denomination, and to the implicated conclusions, comprising conclusion, mathematical operation, and consequence.

The following examples from the English and the Spanish subcorpora illustrate these processes. Concerning explicit meaning, identification and specification processes are related to reference assignment, 
the latter presenting cataphoric elements. Example (1) is an identification of "su concuñada", and example (2) a specification of the cataphoric element "two major problems". Orientation is related to other inferential processes such as further enrichment. Thus, in example (3) the word "demasiado" is clarified.

(1) Resulta que Espósito, conocido por el alias de "La Morca", fue sorprendido por la Policía pasando la noche no con su esposa, sino con su concuñada, es decir, la mujer de Hugo "El Turco" Maradona, el hermano de Diego que juega en Japón. (El Mundo, 5/10/1996, CREA)

[It turns out that Espósito, known by the alias of "La Morca", was surprised by the Police while spending the night not with his wife, but with his sister-in-law, ES DECIR, the wife of Hugo "El Turco" Maradona, Diego's brother who plays in Japan.]

(2) In his opening remarks, Museveni said Africans are confronting two major problems, namely lack of independent decisions and underdevelopement of human resources. (Caribbean Times, 4th May, 1993, COBUILDdirect)

(3) Siria está dispuesta a negociar el calendario de la retirada en etapas si ésta no se alarga demasiado, o sea algo así como tres años. (La Vanguardia, 19/5/1994, CREA)

[Syria is willing to negotiate the withdrawal schedule in stages if it does not take too long, O SEA something like three years.]

In explanation and correction processes, the explicit content of a whole utterance - or a substantial part of itis restated. Correction cases constitute a reorientation more than a rectification. Example (4) is an explanation of a previous quotation ("going to work is fun"), and example (5) is a correction ("al pueblo que gobierna" is reformulated by "en cuyo nombre gobierna", which is not the same).

(4) "Going to work is fun," he [Johnson, a football player] said. That is to say, it takes him out of the all-pervading world of rugby and offers a fresh direction for his talents. (The Times, 20/1/1996, COBUILDdirect)

(5) Necesito creer que [quien gobierna] lo hace por juzgarse más capaz que otro de conducir al pueblo que gobierna - o sea, en cuyo nombre gobierna- hacia un mejor derecho y una más alta calidad de vida. (El Mundo, 27/2/1994, CREA)

[I need to believe that [whoever governs] does so by judging himself more capable than another of leading the people who he governs -O SEA, in whose name he governs- towards better rights and a higher quality of life.]

In English, and in some other languages such as French, there is a third function, which is introduction of restrictions. In example (6), the restriction introduced is a conditional clause.

(6) To get you started we've decorated a selection of small boxes which would make ideal gifts for friends at Christmas that is, if you can bear to give them away! (House Beautiful, November 1993, COBUILDdirect)

In relation to the interpretation of implicit content, at the level of implicated premises, definition and denomination provide the encyclopaedic or conceptual information which is considered necessary. In example (7) o sea introduces a definition of the term "higroscópico", and in example (8), the term "syrup" is introduced by i.e. as a denomination.

(7) Por ello, en las campañas de erradicación de la malaria se rociaban las paredes con DDT, un pesticida muy higroscópico, o sea que absorbe agua. (Geo, July 1995, CREA)

[For this reason, in malaria eradication campaigns, walls were sprayed with DDT, a highly hygroscopic pesticide, O SEA it absorbs water.]

(8) Your pears should be under-ripe because you are going to poach them very gently, and it is very important that they don't go mushy on you. Poach them in apple juice or water and sugar (ie syrup), or even the Gewurztraminer, for perhaps ten minutes at most. (Esquire, September 1992, COBUILDdirect)

Finally, at the level of implicated conclusions, these are made explicit in the processes of conclusion (9), mathematical operation (10), and consequence (11).

(9) Como es natural, toda la prensa publicó fotografías de los jardines y habitaciones de la casa; entre éstas, el dormitorio en el que figuraba sobre la cama matrimonial el retrato de lady Mountbatten pintado por Dalí. Al oírlo éste, soltó una frase que difícilmente olvidaré: La futura reina de Inglaterra perdió, pues, su virginidad bajo mi cuadro, es decir, que, surrealísticamente hablando, yo estaba allí. (La Vanguardia, 9/11/1994, CREA) 
[Naturally, all the press published photographs of the gardens and rooms of the house; among these, the bedroom in which the portrait of Lady Mountbatten painted by Dalí was hanging over the double bed. When he heard it, he uttered a phrase that I will hardly forget: The future queen of England lost, then, her virginity under my painting, ES DECIR, QUE, surrealistically speaking, I was there.]

(10) Thus, a more accurate estimate of the recent unemployment trend is to take the December's 9,700 fall and January's 29,300 drop together and divide them by two in other words, 19,500 a month. (The Times, 17/2/1996, COBUILDdirect)

(11) María Teresa guarda una discreción de ultratumba, pero se adivina que el presupuesto del que dispone su expedición es ridículo. $O$ sea que los descubridores de las civilizaciones bíblicas deben obrar milagros para enriquecer el patrimonio de la humanidad. (El Mundo, 15/8/1996, CREA)

[María Teresa is very discrete, but one can guess that the budget available to her expedition is ridiculous. O SEA QUE the discoverers of biblical civilizations must work miracles to enrich the heritage of humanity.]

Besides these reformulative uses, in Spanish some non-reformulative uses have been pointed out by different authors, including modal uses, with a mitigating or hedging value as in example (12), or with a stressing or boosting value as in example (13).

(12) Pues que pienso que es positivo, porque $o$ sea, a mi modo de ver... (Schwenter 1996: 864-865)

[Well I think that it is positive, because, O SEA, in my view...]

(13) Yo no diría eso o sea (Briz 2001: 218)

[I wouldn't say that O SEA]

\subsection{Positions of reformulation markers}

As stated above, in order to study the variable position, four values were established for the reformulation markers in relation to the discourse member in which they appear, namely, initial, intermediate, final, and independent (following Pons 2014). Initial positions of discourse markers are considered unmarked by Nadal et al. (2016), while intermediate, final and independent positions are considered marked. According to the results of research carried out by these authors by means of eye-tracking reading experiments, discourse markers in marked positions involve greater processing costs, and that may be one of the reasons of their lower general frequency (2016: 67-70).

Example (14) is a case of initial position, example (15) of intermediate position and example (16) of final position. In examples (14) and (15), the markers introduce explicit conclusions; example (16) displays a case of introduction of restrictions.

(14) She faced the fact that he'd cheated on her, felt angry about it, and then tried not to think about it. In other words, she didn't destroy her confidence by dwelling on the bad. (Company, October 1992, COBUILDdirect)

(15) Eso que mi admirado Justino Sinova llama "el vuelco", con acertada expresión, es más bien una lenta caída del Imperio Romano en moviola. Felipe González, o sea, va perdiendo posiciones en Europa porque la propia Europa no sabe adónde va y es mayormente de derechas, aunque hoy nos inerve mucho el socialismo portugués, que se anuncia para "el invierno en Lisboa". (El Mundo, 13/6/1994, CREA)

[What my admired Justino Sinova calls "the overturn", with the right expression, is rather a slow fall of the Roman Empire in moviola. Felipe González, O SEA, is losing positions in Europe because Europe itself does not know where it is going and is mostly right-wing, although today we are greatly stimulated by Portuguese socialism, which is announced for "winter in Lisbon".]

(16) Then came Wednesday's first leg of Wogan's Island, a 10-part travelogue and already an exhausting trip. Exhausting to stay awake in, that is. (Today, 1/7/1995, COBUILDdirect)

O sea is the only marker in the two subcorpora which appears in an independent position, as in example (17):

(17) Este torero cabal, estilista y a la vez valiente, tomó ayer la alternativa en Madrid. Un padrino veterano, Palomo Linares; y un testigo "vip", very important person. O sea. (El Mundo, 26/05/1994, CREA) [This gentle bullfighter, stylist and at the same time brave, took the alternative yesterday in Madrid. A veteran sponsor, Palomo Linares; and a "vip" witness, very important person. O SEA.] 
Regarding the units in which the reformulation markers appear, the Val.Es.Co Group at the University of Valencia (Briz \& Pons 2010) has developed a model of discourse segmentation for the study of conversations and conversational discourse markers, and some of the components of this model may also be applicable to the study of discourse markers in written language. Within this complex model, two units can be relevant for the purposes of this study: acts, which have their own communicative intention and may be identified as fragments delimited by strong punctuation, and subacts, which are the immediate constituents of acts. ${ }^{3}$ Subacts fall into Substantial Subacts (SS), with propositional content, and Adjacent Subacts (AS), with extrapropositional content. In this framework, the reformulation markers themselves constitute adjacent subacts which express instructions to interpret the propositional meaning of the utterances ${ }^{4}$ (cf. Robles 2014) and the members in which they appear may be either acts or subacts. ${ }^{5}$

Examples (15) and (16) above are instances of marked positions in acts, and in example (17), the marker $o$ sea in an independent position constitutes an act in itself. Example (18) illustrates the use of a reformulation marker in intermediate position in a subact (in a process of introduction of restrictions).

(18) The cellar-master at Remy Martin once told me that the French have more than 800 words to describe the taste and aroma a Cognac. Naturally I put this down to Gallic exuberance, until, that is, I decided to read an entire issue of a well-known wine magazine and got severely mugged by a gang of marauding adjectives. (GQ, May 1993, COBUILDdirect)

A more detailed study of the units in which the markers appear is beyond the scope of this study; however, as shall be seen in the examples below, marked positions (intermediate and final) would tend to be more recurrent in acts, rather than in subacts, particularly in Spanish. It may be the case that in these units there would be a greater freedom of movement due to their greater syntactic independence.

\section{Data analysis and results}

In this section the global quantitative results concerning the positions of the markers are presented, followed by those of the two subcorpora with regard to the positions of the different markers, and by quantitative and qualitative data with reference to the reformulative functions they perform in non-initial positions. Finally, modal uses in non-initial positions are accounted for.

\subsection{Global results}

The global results of the analysis are displayed in Table 1.

Table 1: Position of RM in the English and Spanish subcorpora

\begin{tabular}{|l|r|r|r|r|r|r|}
\hline & \multicolumn{2}{|c|}{ Initial } & \multicolumn{2}{c|}{ Intermediate } & \multicolumn{2}{r|}{ Final + Independent } \\
\hline English & 645 & $80.9 \%$ & 68 & $8.5 \%$ & 84 & $10.5 \%$ \\
\hline Spanish & 2,803 & $99.3 \%$ & 6 & $0.2 \%$ & 14 & $0.5 \%$ \\
\hline
\end{tabular}

In this table it can be seen that the quantitative analysis yielded different results in the two subcorpora, which were statistically significant, with low p-values $<0.0001$ in the log-likelihood test for the marked positions in the two languages, taking into account the size of the subcorpora. While in Spanish $99.3 \%$ of the occurrences correspond to initial positions and only $0.7 \%$ to non-initial positions, in English, markers in initial position amount to $80.9 \%$ of the cases, and non-initial position cases reach $19.1 \%$. It can also be appreciated that intermediate positions are the least frequent in the two subcorpora.

\footnotetext{
Hengeveld \& Mackenzie (2008) also distinguish in their model between the act and the subact, and two further types of the latter.

Reformulation markers convey procedural meaning, that is, they indicate how to process content. They also keep some traces of conceptual meaning, as some of their components are related to formulation processes, for example decir, words, etc. (Murillo 2010).

For an alternative analysis of the position of German reformulation markers, following the Basel model for discourse segmentation (Ferrari 2014), see Robles (2019).
} 


\subsection{Results of the English subcorpus: discourse markers and functions}

These results, logically, are not evenly distributed between the different discourse markers. The following table displays the data corresponding to the English subcorpus:

Table 2: Position of RM in the English subcorpus

\begin{tabular}{|l|r|r|r|r|r|r|}
\hline & \multicolumn{2}{|c|}{ Initial } & \multicolumn{2}{c|}{ Intermediate } & \multicolumn{2}{|c|}{ Final } \\
\hline That is & 96 & $43.4 \%$ & 50 & $22.6 \%$ & 75 & $33.9 \%$ \\
\hline That is to say & 19 & $100.0 \%$ & --- & --- & --- & --- \\
\hline I.e. & 218 & $100.0 \%$ & --- & --- & --- & --- \\
\hline In other words & 177 & $87.6 \%$ & 16 & $7.9 \%$ & 9 & $4.5 \%$ \\
\hline Namely & 110 & $100.0 \%$ & --- & --- & --- & --- \\
\hline Viz. & 14 & $100.0 \%$ & --- & --- & --- & --- \\
\hline Another way & 10 & $100.0 \%$ & --- & --- & --- & --- \\
\hline Simply & 1 & $33.3 \%$ & 2 & $66.6 \%$ & --- & --- \\
\hline
\end{tabular}

The marker that moves most freely in its discourse member is that is. Only $43.4 \%$ of the occurrences with that is correspond to initial position, while $33.9 \%$ correspond to final position and $22.6 \%$ to intermediate position. In other words was also found in the three positions, but its frequency in non-initial positions is much lower than that of that is. Then, to put it simply, which is a less grammaticalized marker, was also found in initial and in intermediate positions, although not very frequently. The rest of the markers were only found in initial positions in the subcorpus. The different functions performed by markers in a non-initial position are displayed in Table 3:

Table 3: Non-initial position of English RM in relation to their reformulative uses

\begin{tabular}{|c|c|c|c|c|c|c|}
\hline & \multicolumn{2}{|c|}{ That is } & \multicolumn{2}{|c|}{ In other words } & \multicolumn{2}{|c|}{ To put it simply } \\
\hline & Non-initial & Total cases & Non-initial & Total cases & Non- initial & Total cases \\
\hline Identification & $21(87,5 \%)$ & 24 & --- & 1 & --- & -- \\
\hline Specification & --- & 10 & --- & 5 & --- & --- \\
\hline Orientation & $16(94.1 \%)$ & 17 & --- & 1 & --- & -- \\
\hline Explanation & $8(17.4 \%)$ & 46 & $3(7.5 \%)$ & 40 & --- & --- \\
\hline Intr. Restrictions & $69(79.3 \%)$ & 87 & --- & --- & --- & -- \\
\hline Correction & $6(85.7 \%)$ & 7 & --- & --- & --- & -- \\
\hline Definition & 1 & 18 & --- & 12 & --- & --- \\
\hline Denomination & --- & 1 & 1 & 1 & --- & -- \\
\hline Conclusion & 3 & 7 & $18(16.1 \%)$ & 112 & 2 & 3 \\
\hline Mathematical Op. & 1 & 3 & 2 & 7 & --- & -- \\
\hline Consequence & --- & 1 & 1 & 23 & --- & -- \\
\hline
\end{tabular}

With respect to the discourse processes, that is in a non-initial position is very frequent in processes of introduction of restrictions, with 69 cases or $79.3 \%$ of the examples with this discourse process. This marker is also frequent in these positions in identification (with 21 cases or $83.3 \%$ of the cases of identification marked by that is), orientation ( 16 or $88.2 \%$ ) and correction processes ( 6 cases or $85.7 \%$ ). All these cases are related to repairs (identification and orientation cases), corrections or counterargumentations (introduction of restrictions).

It is also interesting to highlight that in other words in non-initial positions appeared mainly in conclusions (in 18 cases or $16.1 \%$ of all the conclusion cases introduced by in other words), although these data represent a lower relative frequency.

In what follows, the most recurring cases are considered. Examples (19) and (20) illustrate the occurrence of that is in final position in processes of identification and orientation, in a subact:

(19) We're ready for them, the jokes that is. (The Times, 6/1/1996, COBUILDdirect) (Identification) 
(20) Yorkshiremen recognise no fish but haddock, and indeed that fish's distinctive flavour and slightly drier flesh (in comparison to cod, that is) does seem best suited to batter. (Harpers and Queen, October 1993, COBUILDdirect) (Orientation)

That is also appears frequently in final position in this discourse process of introduction of restrictions, as in example (21), in an act:

(21) Notice anything different about Tim Flowers? Apart from the England goalkeeping jersey, that is? That's right, he's had a haircut! (90 Minutes, 3/7/1993, COBUILDdirect) (Introduction of restrictions)

And it also marks cases of correction, in final position, as in example (22), also in an act:

(22) The best example is motor racing. Formula One that is, not IndyCar. (Today, 31/7/1995, COBUILDdirect) (Correction)

In intermediate positions, that is can appear following conjunctions and prepositions in processes of introduction of restrictions. Example (23) corresponds to an occurrence with "unless" in an act. In these cases, which are quite frequent, the RM is used to give prominence to these elements, thus stressing the restrictions.

(23) Here is a task for Sir Christopher Bland, the BBC's new, super-bright chairman: designing a socially useful penance for fee evaders. How about reading to the blind? Unless, that is, the blind are fee-evaders themselves. (The Times, 10/4/1996, COBUILDdirect) (Introduction of restrictions)

That is and in other words can be used in an intermediate position to "recover" an element from a previous clause and to introduce afterwards some sort of explanation. In example (24) the recovered element is "extinction" and in (25), the adjective "best/better".

(24) The second instalment in Mr McCartney's musical odyssey corresponds with a time when his exalted ilk were condemned to certain extinction. Extinction, that is, by the tidal ferocity of the New Wave as it swept away nostalgia like 'Jet', Another Day Silly Love Songs' and 'Mull Of Kintyre', to renew the land for Ian Curtis, Thatcherism and impending world-wide environmental disaster. (Vox, October 1993, COBUILDdirect) (Explanantion)

(25) I don't think he has ever come on that strongly," Courier said, "and that was the best I've played in the tournament." Better, in other words, than his own revivals against Todd Woodbridge and Marcos Ondruska, both of whom had been 2-1 ahead in sets in the previous two rounds. (The Times, 25/1/1996 COBUILDdirect) (Explanation)

Examples (26), (27) and (28) illustrate how the three markers that is, in other words and to put it simply can appear in an intermediate position in order to hihglight or emphasize the subject of an independent clause, syntactically and prosodically, indicating some sort of change with respect to the previous discourse in a conclusion process. The reformulations in all these examples, as well as those in (24-25) correspond to acts:

(26) But in opting so strongly for the fantastic, Frauds forfeits both its dramatic bite and its modest theme "men just won't grow up." The real joke, that is, may well be on its director. (Harpers and Queen, June 1993, COBUILDdirect) (Conclusion)

(27) Among the statistics released last week was the real shocker: one-third of British homes have three or more television sets. Television, in other words, is increasingly a solitary experience. (The Times, 20/12/1995, COBUILDdirect) (Conclusion)

(28) This can be taken on two levels. The microeconomic case for lower taxes to boost incentives is a constant. But there is also a powerful macroeconomic case. Demand, to put it simply, could do with a lift. (The Times, 18/11/1995, COBUILDdirect) (Conclusion)

\subsection{Results of the Spanish subcorpus: discourse markers and functions}

Regarding reformulation markers in the Spanish subcorpus, Table 4 presents the results for the variable positon.

Table 4: Position of RM in the Spanish subcorpus

\begin{tabular}{|l|r|r|r|r|r|r|r|r|}
\hline & \multicolumn{2}{|c|}{ Initial } & \multicolumn{2}{c|}{ Intermediate } & \multicolumn{2}{c|}{ Final } & \multicolumn{2}{c|}{ Independent } \\
\hline Es decir & 1,858 & $99.9 \%$ & 1 & $0.1 \%$ & --- & --- & -- & --- \\
\hline O sea & 467 & $96.3 \%$ & 4 & $0.8 \%$ & 11 & $2.3 \%$ & 3 & $0.6 \%$ \\
\hline Esto es & 213 & $100.0 \%$ & --- & --- & --- & --- & --- & --- \\
\hline
\end{tabular}




\begin{tabular}{|c|c|c|c|c|c|c|c|c|}
\hline A saber & 42 & $100.0 \%$ & --- & --- & --- & --- & --- & --- \\
\hline Con otras palabras & 3 & $100.0 \%$ & --- & --- & --- & --- & --- & --- \\
\hline En otras palabras & 71 & $100.0 \%$ & --- & --- & --- & --- & --- & --- \\
\hline En otros términos & 6 & $100.0 \%$ & --- & --- & --- & --- & --- & --- \\
\hline De otra forma & 8 & $100.0 \%$ & --- & --- & --- & --- & --- & --- \\
\hline De otro modo & 24 & $96.0 \%$ & 1 & $4.0 \%$ & --- & --- & --- & --- \\
\hline De otra manera & 18 & $100.0 \%$ & --- & --- & --- & --- & --- & --- \\
\hline O lo que es lo mismo & 62 & $100.0 \%$ & --- & --- & --- & --- & --- & --- \\
\hline Léase & 31 & $100.0 \%$ & --- & --- & --- & --- & --- & --- \\
\hline
\end{tabular}

Reformulation markers in Spanish tend to appear in initial position, although a few examples were documented in other positions. The functional range is much more limited than in English. In all the examples from the corpus that follow, the unit in which the reformulation marker is inserted is an act.

O sea was found in conclusions in intermediate positions in clauses, both after adverbs, as in example (29) and after the subject, as in example (30); in both cases, the reformulation markers are being used to highlight these initial elements.

(29) Lo que mejor hace Pedro es irse a ese Rastro del contraespionaje los domingos por la mañana, allí donde se vocean en voz baja las cuentas de Javi Rosa contra los calderos de Palomino: el que hace un caldero hace ciento, que el búnker de Moncloa hasta tiene calderos para las goteras. Aquí, o sea, todo es ya calderería y numismática negra, del dinero negro de la corrupción, mayormente, todo es lavandería, mi hermosa lavandería, donde se blanquean y planchan divisas, todo es plusvalía, palancazo y papel del Estado. (El Mundo, 10/11/1994, CREA) (Conclusion)

[What Pedro does best is go to that counterintelligence Flee Market on Sunday mornings, where Javi Rosa's accounts are shouted in a low voice against Palomino's cauldrons: he who makes a cauldron makes a hundred; the bunker in Moncloa even has cauldrons for leaks. Here, O SEA, everything is already black metalwork and numismatics, from the black money of corruption, mostly, everything is launderette, my beautiful launderette, where currencies are laundered and ironed, everything is surplus value, leverage and role of the State.]

(30) El conde está tieso y no sabe cómo arreglárselas para llegar a fin de mes. Se le ha visto en varios puntos de la geografía española poniéndoles cara de asco a los fotógrafos, al tiempo que intentaba meter la pelotita de golf en un agujerito. Se trataba -obvio es destacarlo- de una pura maniobra de despiste, porque fuentes bien informadas aseguran que el conde se corre de gusto cada vez que oye el suave click de una cámara zumbándole en la oreja.

El conde, o sea, trata de labrarse un futuro a toda costa (un futuro y un presente, pues tiene que pagar puntualmente el recibo de la luz), así que se aferra a los muslos de Ana Obregón para asegurarse la propina de los medios del ramo. (El Mundo, 23/8/1996, CREA) (Conclusion)

[The count is broke and does not know how to manage to make ends meet. He has been seen in various parts of the Spanish geography pulling a face of disgust to photographers, while trying to put the little golf ball in a little hole. It was -it is obvious to highlight-a pure diversionary manoeuvre, because wellinformed sources assure that the count cums with pleasure every time he hears the soft click of a camera buzzing in his ear.

The count, O SEA, tries to carve out a future at all costs (a future and a present, since he has to pay the electricity bill on time), so he clings to Ana Obregón's thighs to secure the tip of the media.]

Some marginal cases of explanation and correction were also documented with o sea in intermediate position:

(31) Eso que mi admirado Justino Sinova llama "el vuelco", con acertada expresión, es más bien una lenta caída del Imperio Romano en moviola. Felipe González, o sea, va perdiendo posiciones en Europa porque la propia Europa no sabe adónde va y es mayormente de derechas, aunque hoy nos inerve mucho el socialismo portugués, que se anuncia para "el invierno en Lisboa". (El Mundo, 13/6/1994) (Explanation)

[What my admired Justino Sinova calls "the overturn", with the right expression, is rather a slow fall of the Roman Empire in moviola. Felipe González, O SEA, is losing positions in Europe because Europe itself does not know where it is going and is mostly right-wing, although today we are greatly stimulated by Portuguese socialism, which is announced for "winter in Lisbon".] 
(32) El Gobierno estudia la posibilidad de cobrar por respirar. No es seguro, o sea, pero si las tasas sobre el agua funcionan, lo siguiente va a ser cobrar por respirar. (El Mundo, 28/7/1996) (Correction)

[The Government is studying the possibility of charging for breathing. It's not certain, O SEA, but if the water charges work, the next thing is going to be charging for breathing.]

In relation to intermediate position in clauses, es decir and de otro modo were found with one case each:

(33) Si, como su admirado Godard, Tarantino se comiese algún libro mientras devora películas y tele, quizá descubriría que trastocar la linealidad de una historia -como en "Rashomon", que le encanta- no sólo sirve para que el público se entretenga, o reordene mentalmente la sucesión de los hechos, sino para que después, en la calle o en la cama, se abra la cabeza decidiendo cuál de los antagonistas tenía razón, y acaso se juegue por una alternativa. Sirve, es decir, para que el sentido se prolongue más allá de cualquier forma de las llamadas redondas. (La Vanguardia, 30/05/1995, CREA) (Conclusion)

[If, like his admired Godard, Tarantino ate a book while devouring movies and TV, perhaps he would discover that disrupting the linearity of a story -as in "Rashomon", which he loves- not only serves to entertain the public, or make them rearrange mentally the sequence of events, but so that later, on the street or in bed, they rack their brains deciding which of the antagonists was right, and perhaps they play for an alternative. It serves, ES DECIR, for the meaning to extend beyond any form of the so-called round.]

(34) Es conocida la preocupación de Manolo Valdés por lo que la historia hará con las obras contemporáneas que ahora entran en los museos. El que es un estudioso del Siglo de Oro español, proporciona, con su producción más reciente, claves para romper esa tendencia, casi universal, al explicar la obra de arte contando su argumento. De hecho utiliza figuras históricas de fuerte carácter, incorporadas en piezas rotundas dentro de la tradición pictórica, casi siempre presentes en el Museo del Prado. Explota, por decirlo de otro modo, una buena parte de nuestro legado visual. (ABC Cultural, 31/05/1996, CREA) (Conclusion)

[Manolo Valdés's concern for what history will do with contemporary works that now enter museums is well known. As a student of the Spanish Golden Age, he provides, with his most recent production, keys to break this almost universal trend, by accounting for the works of art by explaining their plots. In fact, he uses historical figures of strong character, incorporated into resounding pieces within the pictorial tradition, almost always present in the Prado Museum. He exploits, POR DECIRLO DE OTRO MODO, a good part of our visual heritage.]

As pointed out above, only o sea appeared in final position, in conclusive uses, as in example (35).

(35) Ojo. Decía don Eugenio d'Ors que "lo malo del que sufre manía persecutoria es que tiene razón”. La persecución la engendra previamente la manía, o sea. (El Mundo, 11/11/1996, CREA) (Conclusion) [Careful. Don Eugenio d'Ors used to say that "the bad thing about a man who suffers from persecutory delusions is that he is right". The persecution is previously engendered by the delusions, O SEA.]

\subsection{Modal uses in the English and Spanish subcorpora}

Modal uses, with reinforcing or mitigating values, are associated to some cases of non-initial positions of the reformulation markers. Modal reinforcement cases were found in the two subcorpora of this study, but with different orientations. In English, emphatic uses appear exclusively with that is in processes of identification, which are counterargumentative and are related to humor. In these examples that is occupies a final position in an act:

(36) See that wrinkled old git on the air scooter? That's you that is. (Melody Maker, 15/5/1993, COBUILDdirect) (Identification + Modal)

The second part of this reformulation can be translated into Spanish with an expression such as: “¡Pero si eres tú!” or "¡Pues eres tú!”. These cases are colloquial and come from magazines.

In the Spanish subcorpus, only o sea was found in modal reinforcing uses, mainly in opinion articles (cf. Briz 2002; Mancera 2008). These modal uses of $o$ sea seem very idiosyncratic, as they are used by authors like Francisco Umbral and Arturo Pérez Reverte. In these uses in the Spanish subcorpus, conclusion is the most frequent function. The marker appears in final position, as in example (37):

(37) Estamos en plena involución social, política, nacional, y a la puerta del teatro había una mujer dormida en el suelo, una mendiga que pronto recogerá el CESID para sus experimentos con vistas al Nobel de 
ciencia. Por San Jerónimo subía una manifestación de funcionarios congelados. Es la rentrée, o sea. (El Mundo, 21/9/1996, CREA) (Conclusion + Modal)

[We are in full social, political, and national involution, and at the door of the theater there was a woman asleep on the floor, a beggar who will soon be picked up by the CESID for its experiments with a view to the Nobel Prize in science. By San Jerónimo a demonstration of civil servants with frozen salaries went up. The autumn season is here, O SEA.]

These examples present a combination of reformulation and modal uses. Schwenter (1996: 868-872) showed that $o$ sea can carry out these two tasks at the same time, although he focused on mitigation or hedging uses. This author concluded that "there seems to be a hybrid DM category that includes $o$ sea", and he expressed the need to check this category cross-linguistically (1996: 870). In this line, the uses of that is showing a combination of discourse process of identification together with modality would indicate that such combinations may be present in other languages besides Spanish.

Further, in some of the examples, $o$ sea does not perform a reformulative role, as it is used as a modal particle exclusively, as a discourse operator. Example (38) corresponds to the beginning of an article, and therefore $o$ sea cannot be reformulating anything:

(38) Lo del vídeo del PSOE contra Aznar a mí me gusta, o sea. Quiero decir que la escuela cinematográfica de Felipe González han hecho un vídeo expresionista, a lo Kusturica. (El Mundo, 20/2/1996) (Modal) [I like the video of PSOE against Aznar, O SEA. I mean that the film school of Felipe González have made an expressionist video, a la Kusturica.]

This modal o sea usually appears in final position, as in the previous cases, but it can also appear in an intermediate position, as in example (39) -this example is also the first sentence of an article- or may even be used after a stop and become an independent act as in example (40):

(39) A uno le alegra, o sea, que Javi Rosa haya salido del trullo Can Brians de Barcelona, porque Javi, aunque tan triste, coñazo y carnosito, alegraba mucho las noches de Madrid, mayormente por la aureola de millones que siempre le seguía, y que algunos cazaban como moscas, en el aire, o como esos moscones de verano que giran en torno a los ventiladores "Casablanca" del Hispano/Bar. (El Mundo, 15/2/1995, CREA) (Modal)

[One is happy, O SEA, that Javi Rosa has left the Can Brians slammer in Barcelona, because Javi, although so sad, boring and meaty, made Madrid nights very happy, mainly because of the aura of millions that always followed him, and that some hunted like flies, in the air, or like those summer flies that revolve around the "Casablanca" fans of the Hispano/Bar.]

(40) La que guía los pasos del alcalde es su segunda, Esperanza Aguirre, concejala de Medio Ambiente, que en uno de los descansos le entrega a Manzano una nota en la que se lee: "Habla de lo que a ti te interesa. Chuleta". O sea. (El Mundo, 10/5/1995, CREA) (Modal)

[The one who guides the steps of the mayor is his second, Esperanza Aguirre, Councilor for the Environment, who in one of the breaks gives Manzano a note that reads: "Talk about what interests you. Cheat sheet". O SEA.]

In all these examples of modal uses the reformulations constitute separate acts. It would perhaps be reasonable to think that cases like those of examples (37), (38) and (39) have had an influence on the development of the modal independent value of $o$ sea illustrated in (40) (cf. Pons 2014, 2016). A sequence may be perceived as follows: first, a combination of conclusion and modal uses, with the marker in final position, then exclusively modal uses with the marker in intermediate and final positions, and lastly an independent use of the marker, constituting an act in itself.

\section{Concluding remarks}

The present paper has studied non-initial positions of explanatory reformulation markers in written language in English and Spanish, in relation to their discursive uses (reformulative and modal). In general, the results reveal that reformulation markers in English - particularly that is-, display far more mobility than in Spanish. $O$ sea is the only marker that has mobility in Spanish, and this marker is also the only one in the two languages that appears independently. Regarding their reformulation uses, markers in non-initial positions follow different trends in the two languages. In English, non-initial positions are mainly associated to counterargumentative uses, or repair and correction uses. In Spanish, they are associated to conclusion uses. In modal uses they also follow different trends. In English they reinforce identification uses; in Spanish, they reinforce conclusions, with a progressive movement towards exclusively modal values. Non-initial positions tend to be more frequent in acts due perhaps to the greater syntactic independence of these units. 
Going back to Nadal et al.'s experimental studies (2016), they reach the following general conclusions regarding discourse markers in non-initial, marked positions:

From the point of view of positional mobility, speakers systematically distinguish between an unmarked position, the initial one, and marked positions, the middle and the final ones. In this way, speakers assign more processing costs to marked positions and therefore the door opens to two possibilities:

a. first, that these options are abandoned (they are structurally weak positions because they are less frequent);

b. second, that new semantic values and functions are assigned to these positions. (2016: 70, my translation)

After analyzing the data presented here, possibility a) (that these marked positions are abandoned) is confirmed in Spanish, as their frequency is low; by contrast, in English there seem to be markers which are specialized in moving inside their discourse member, and this may be attributed to a cost-benefit relationship. Possibility b) (that these positions acquire new semantic values and functions) is confirmed as regards the modal uses, particularly in Spanish.

The functional spaces occupied in English by reformulation markers with mobility might be occupied in Spanish by other types of markers like the counterargumentative connector eso si (for the introduction of restrictions). More research needs to be carried out along that line, and also in relation to the discourse units that host reformulation markers.

In any case, the quantitative research carried out has revealed relevant intra- and cross-linguistic differences between the markers analyzed, allowing us to compare them from a tangible point of view, not merely based on general impressions. The results derived from this work should be taken into account by professional translators, and also by those in charge of providing translator training. In addition, this type of research can find an application in the compilation of dictionaries. Bilingual dictionaries tend to use synonyms in the descriptions of discourse markers, and to consider synonyms those markers which are partly coincident in their meanings. A lot remains to be done with regard to bilingual discourse marker dictionaries, and studies like the present one can provide insights for this task.

\section{References}

Archakis, Argiris (2001). On Discourse Markers: Evidence from Modern Greek. Journal of Pragmatics 33, 8: 1235-1261. https://doi.org/10.1016/S0378-2166(00)00054-0

Bach, Carme (2017). Les marqueurs de reformulation paraphrastique du catalan: une clase homogène? Pragmalingüistica, Monográfico 1: 152-170. https://revistas.uca.es/index.php/pragma/article/view/2426/3933

Beeching, Kate and Ulrich Detges, eds. (2014). Discourse Functions at the Left and Right Periphery: Crosslinguistic Investigations of Language Use and Language Change. Leiden, The Netherlands: Brill.

Blakemore, Diane (1993). The Relevance of Reformulations. Language and Literature 2, 2: 101-120. https://doi. org/10.1177/096394709300200202

Blakemore, Diane (1996). Are Apposition Markers Discourse Markers? Journal of Linguistics 32, 2: 325-347. https://doi. org/10.1017/S0022226700015917

Borreguero Zuloaga, Margarita and Sonia Gómez-Jordana Ferary, eds. (2015). Marqueurs du discours dans le langues romanes: une approche contrastive. Limoges: Lambert-Lucas.

Borreguero Zuloaga, Margarita (2014). Left Periphery in Discourse: Frame Units and Discourse Markers. In Dufter, Andreas and Álvaro S. Octavio de Toledo, eds., 345-382. https://doi.org/10.1075/la.214.18bor

Briz, Antonio (2001). El uso de o sea en la conversación. In de Kock, Josse, ed., 287-318.

Briz, Antonio (2002). Otra vez sobre o sea. In Saralegui Platero, Carmen and Manuel Casado Velarde, eds., 169-190.

Briz, Antonio and Salvador Pons (2010). Unidades, marcadores discursivos y posición. In Loureda, Óscar and Esperanza Acín, eds., 327-358.

Casado Velarde, Manuel (1991). Los operadores discursivos es decir, esto es, o sea y a saber en español actual: valores de lengua y funciones textuales. Lingüistica Española Actual XIII: 87-116.

Charolles, Michel and Danièle Coltier (1986). Le contrôle de la compréhension dans une activité rédactionnelle: Éléments pour l'analyse des reformulations paraphrastiques. Pratiques 49: 51-66. https://www.persee.fr/doc/ prati_0338-2389_1986_num_49_1_2450

Cuenca, M. Josep (2003). Two Ways to Reformulate: A Contrastive Analysis of Reformulation Markers. Journal of Pragmatics 35, 7: 1069-1093. https://doi.org/10.1016/S0378-2166(03)00004-3

Cuenca, M. Josep and Carme Bach (2007). Contrasting the Form and Use of Reformulation Markers. Discourse Studies 9, 2: 149-175. https://doi.org/10.1177/1461445607075347

De Kock, Josse, ed. (2001). Gramática española, enseñanza e investigación: Lingüística con corpus. Catorce aplicaciones sobre el español. Salamanca: Ediciones Universidad.

Del Saz, M. Milagros (2003). An Analysis of English Discourse Markers of Reformulation. PhD dissertation, València: Universitat de València, Servei de Publicacions. https://www.tdx.cat/handle/10803/9778 
Dufter, Andreas and Álvaro S. Octavio de Toledo, eds. (2014). Left Sentence Peripheries in Spanish: Diachronic, Variationist and Comparative Perspectives. Amsterdam: John Benjamins.

Escandell, M. Victoria, José Amenós and Aoife K. Ahern, eds. (2021). Pragmática. Madrid: Akal.

Estellés Arguedas, María and Salvador Pons Bordería (2014). Absolute Initial Position. In Pons Bordería, Salvador, ed., 121-155. https://doi.org/10.1075/pbns.250.05est

Ferrari, Angela (2014). The Basel Model for Paragraph Segmentation: The Construction Units, their Relationships and Linguistic Indication. In Pons Bordería, Salvador, ed., 23-53. https://doi.org/10.1075/pbns.250.02fer

Fløttum, Kjersti (1994). À propos de c'est-à-dire et ses correspondants norvégiens. Cahiers de Linguistique Française 15: 109-130. https://clf.unige.ch/files/8114/4103/2937/05-Flottum_nclf15.pdf

Garcés Gómez, M. Pilar (2008). La organización del discurso: marcadores de ordenación y de reformulación. Madrid / Frankfurt: Iberoamericana / Vervuert.

Garcés Gómez, M. Pilar, ed. (2009). La reformulación del discurso en español en comparación con otras lenguas (catalán, francés, italiano, inglés, alemán e islandés). Madrid. BOE / Universidad Carlos III de Madrid.

Ghezzi, Chiara and Piera Molinelli (2014). Italian guarda, prego, dai. Pragmatic Markers and the Left and Right Periphery. In Beeching, Kate and Ulrich Detges, eds., 117-150. https://doi.org/10.1163/9789004274822_007

Ghezzi, Chiara and Piera Molinelli, eds. (2014). Discourse and Pragmatic Markers from Latin to the Romance Languages. Oxford: Oxford University Press.

Guillén Escamilla, Josaphat Enrique (2018). Hacia una caracterización funcional de fijarse como marcador del discurso. Pragmalingüística 26: 131-147. http://dx.doi.org/10.25267/Pragmalinguistica.2018.i26.07

Gülich, Elisabeth and Thomas Kotschi (1983). Les marqueurs de la reformulation paraphrastique. Cahiers de Linguistique Française 5: 305-351. https://clf.unige.ch/files/3514/4111/1825/13-Gulich_nclf5.pdf

Gutiérrez-Rexach, Javier, ed. (2016). Enciclopedia de Lingüistica Hispánica. New York: Routledge.

Hengeveld, Kees and J. Lachlan Mackenzie (2008). Functional Discourse Grammar. A Typologically-Based Theory of Language Structure. Oxford: Oxford University Press.

Loureda, Óscar and Esperaza Acín, eds. (2010). Los estudios sobre marcadores del discurso en español, hoy. Madrid: Arco Libros.

Mancera, Ana (2008). La reformulación en el discurso periodístico: una muestra de oralidad fingida. Oralia. Análisis del discurso oral 11: 353-374.

Matsui, Tomoko (2002). Semantics and Pragmatics of a Japanese Discourse Marker dakara (so/ in other words): A Unitary Account. Journal of Pragmatics 34 (7): 867-891. https://doi.org/10.1016/S0378-2166(01)00066-2

Montañez Mesas, Marta P. (2007). Marcadores del discurso y posición final: la forma ¿eh? en la conversación coloquial española. ELUA. Estudios de Lingüística 21:261-280. https://rua.ua.es/dspace/bitstream/10045/9941/1/ELUA_21_13. pdf

Murat, Michel and Bernard Cartier-Bresson (1987). C'est-à-dire ou la reprise interprétative. Langue Française 73, La reformulation du sens dans le discours: 5-15. https://www.persee.fr/doc/lfr_0023-8368_1987_num_73_1_6425

Murillo, Silvia (2009). Los marcadores de reformulación explicativa en español y en inglés: estudio contrastivo de $o$ sea y sus traducciones that is (to say) e in other words. In Garcés Gómez, M. Pilar, ed., 137-161.

Murillo, Silvia (2010). Los marcadores del discurso y su semántica. In Loureda, Óscar and Esperanza Acín, eds., $241-280$.

Murillo, Silvia (2012). The Use of Reformulation Markers in Business Management Research Articles: An Intercultural Analysis. International Journal of Corpus Linguistics 17, 1: 62-88. https://doi.org/10.1075/ijcl.17.1.03mur

Murillo, Silvia (2015). Sobre el uso de que con los marcadores de reformulación explicativa en español escrito. In Borreguero Zuloaga, Margarita and Sonia Gómez-Jordana Ferary, eds., 155-164.

Murillo, Silvia (2016a). Reformulation Markers and Polyphony: A Contrastive English-Spanish Analysis. Languages in Contrast 16, 1: 1-30. https://doi.org/10.1075/lic.16.1.01mur

Murillo, Silvia (2016b). Sobre la reformulación y sus marcadores. Cuadernos AISPI 8: 237-258.

Nadal, Laura, Adriana Cruz, Inés Recio and Óscar Loureda (2016). El significado procedimental y las partículas discursivas del español: Una aproximación experimental. Revista Signos. Estudios de Lingüística 49 (S1): 52-77. http://dx.doi. org/10.4067/S0718-09342016000400004

Pons Bordería, Salvador (2008). La combinación de marcadores del discurso en la conversación coloquial: interacciones entre posición y función. Estudos Linguísticos/Linguistic Studies 2, Lisboa: Ediçoes Colibri / CLUNL: $141-159$. https://clunl.fcsh.unl.pt/wp-content/uploads/sites/12/2018/02/2h-salvador-borderia.pdf

Pons Bordería, Salvador (2014). Paths of Grammaticalization in Spanish o sea. In Ghezzi, Chiara and Piera Molinelli, eds., 109-136. http://doi.org/10.1093/acprof:oso/9780199681600.003.0007

Pons Bordería, Salvador, ed. (2014). Discourse Segmentation in Romance Languages. Amsterdam: John Benjamins.

Pons Bordería, Salvador (2016). Evolución diacrónica de o sea. Boletín de la Real Academia Española, Tomo XCVI Cuaderno CCCXIII: 291-350. http://revistas.rae.es/brae/article/view/140/279

Pons Bordería, Salvador and Ana Cristina Lopes Macário (2014). Ou seja vs. O sea: Formal Identity and Functional Diversity. Revista de Estudos Linguísticos da Universidade do Porto 9: 103-128. https://ojs.letras.up.pt/index.php/ EL/article/view/2684/2471

Portolés, José (2016). Marcadores del discurso. In Gutiérrez-Rexach, Javier, ed., 689-699. 
Portolés, José, Eugenia Sainz and Silvia Murillo (2021). Partículas discursivas e instrucciones de procesamiento. In Escandell, M. Victoria, José Amenós and Aoife K. Ahern, eds., 284-302.

Quirk, Randolph, Sidney Greenbaum, Geoffrey Leech and Jan Svartvik (1985). A Comprehensive Grammar of the English Language. London: Longman.

Riegel, Martin and Irène Tamba (1987). Présentation. Langue Française 73, La reformulation du sens dans le discours: 3-4. https://www.persee.fr/doc/lfr_0023-8368_1987_num_73_1_6424

Robles i Sabater, Ferran (2012). Los marcadores de reformulación alemanes: estudio preliminar. Revista de Filología Alemana 20: 159-179.

Robles i Sabater, Ferran (2014). Estructura informativa y reformulación: los recapitulativos kurz gesagt y mit einen wort. Revista de Filología Alemana 22: 207-226. http://dx.doi.org/10.5209/rev_RFAL.2014.v22.45317

Robles i Sabater, Ferran (2019). Marcadores del discurso y organización informativa del enunciado: los reformuladores explicativos alemanes. Revista de Filología Alemana 27: 153-175. https://dx.doi.org/10.5209/rfal.64356

Saralegui Platero, Carmen and Manuel Casado Velarde, eds. (2002). Pulchre, bene, recte. Estudios en Homenaje al Prof. Fernando González Ollé. Pamplona: EUNSA.

Schwenter, Scott A. (1996). Some Reflections on 'o sea': A Discourse Marker in Spanish. Journal of Pragmatics 25 (6): 855-874. https://doi.org/10.1016/0378-2166(95)00023-2

Sperber, Dan and Deirdre Wilson (1986/1995). Relevance: Communication and Cognition. Oxford: Blackwell.

Tanghe, Sanne (2016). Position and Polyfunctionality of Discourse Markers: The Case of Spanish Markers Derived from Motion Verbs. Journal of Pragmatics 93: 16-31. https://doi.org/10.1016/j.pragma.2015.12.002

Tognini-Bonelli, Elena (2001). Corpus Linguistics at Work. Amsterdam: John Benjamins. https://doi.org/10.1075/scl.6

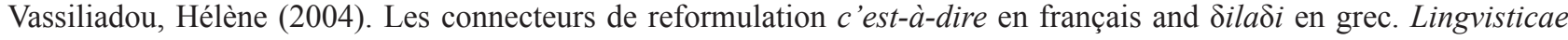
Investigationes 27, 1: 125-146. https://doi.org/10.1075/li.27.1.06vas 